Marjet Derks* and Elisa Rodenburg

\title{
A Bastion against Assimilation? Jewish sport in the Netherlands, 1890-1940
}

DOI 10.1515/asch-2017-0008

\begin{abstract}
Dieser Beitrag diskutiert jüdische Sportkulturen in den Niederlanden vor dem Zweiten Weltkrieg. Dabei soll das bisherige Konzept einer vorwiegend segregierten und zionistisch geprägten jüdischen Sportkultur als Ergebnis einer aus der Nachkriegszeit stammenden Sichtweise revidiert werden. Anhand des Beispiels von drei jüdischen Gemeinden, Amsterdam, Groningen und Den Haag, zwischen dem Ende des 19. Jahrhunderts und 1940 wird aufgezeigt, dass die jüdische Sportszene zugleich »assimiliert « und heterogen war, und dass sie Vereine verschiedener sozialer, politischer und religiöser Orientierung umfasste. Wegen des hohen Grads an Integration in die niederländische Gesellschaft, spielte die Frage der niederländischen Identität keine Rolle. Vielmehr beeinflusste die soziale Klasse Fragen von Inklusion und Exklusion. In den 1920er und 1930er Jahren stieg die Anzahl separater jüdischer Vereine ebenso wie die Verbreitung des Zionismus, wenngleich letzterer im Sport ebenso wie das Ideal des Muskeljudentums umstritten blieb. Jüdischer Sport in den Niederlanden war daher weder so profiliert wie anderswo noch ein Instrument der Integration.
\end{abstract}

\section{Introduction}

»Yes, we are super Jews! And can they play football? As long as they play for Ajax«, chanted a group of ultras, supporters of Ajax Amsterdam, during the match against FC Rostov on 16 August 2016. Ajax Amsterdam shares the fate of Tottenham Hotspur, where non-Jewish supporters - in some cases hooligans have appropriated Jewish identity and proudly call themselves Jews. Although the assumption of a Jewish identity by football supporters »has less to do with traditional associations and the specific sociology of Jewish life [...] than with the

*Corresponding author: Marjet Derks, m.derks@let.ru.nl 
rise of racist hooliganism in the 1970s«, the Ajax supporters' claim does refer to an interesting yet complex past. ${ }^{1}$

In the 1950s, Ajax players and managers felt a definite sense of identity connected to (the no longer existing) Jewish Amsterdam. ${ }^{2}$ Before the war, the Ajax fan base consisted of people living in the eastern part of Amsterdam's city centre, traditionally a Jewish neighbourhood. However, most of these Jews could not afford membership. According to football historian Simon Kuper it still makes sense to call Amsterdam a Jewish club because of its Jewish fan base, its cultural ties with prominent Dutch Jews and its festivities in an Amsterdam café that was usually frequented by Jewish socialists. Pre-war Jewish Ajax fan Abraham Roet, however, disagrees, because being Jewish »was not the point. Judaism was never a problem in the Netherlands. You never felt different. « Instead of calling Ajax a Jewish club, Roet would prefer to define it as a »melting pot «. ${ }^{3}$

The example of Ajax touches upon a relatively unexplored part of Dutch Jewish history: Jewish sport, which boomed between 1890 and 1940. The complexity of this history is deepened by the Second World War. In his book Joodse stadjers (Jewish city dwellers) historian Stefan Van der Poel analyses Jewish culture in the northern city of Groningen and warns against looking at pre-war Jewish communities in the Netherlands from a post-war point of view:

When describing and researching such a period, there exists a danger that the Second World War foreshadows the work and that the author starts to consider the entire pre-war period as the introduction to that war. From that point of view, the aspiration for assimilation is easily stigmatised negatively, because one asks to what it has led in the end. ${ }^{4}$

A similar remark had been made five years earlier: in an article on Jewish sport in the Netherlands, German sport philosopher Arnd Krüger and his Dutch co-researcher Astrid Sanders noted an imbalance in the attention being given to the Zionist Maccabi sport tradition, both within the (scarce) historical research and the collective memory. Jewish sport that aligned with Max Nordau's concept of muscular Judaism - including German-oriented gymnastics and boxing - has been accen-

1 John Efron: When Is a Yid Not a Jew? The Strange Case of Supporter Identity at Tottenham Hotspur. In: Emancipation through Muscles. Ed. by Michael BRENNER and Gideon ReuvenI. Lincoln, London 2006, p. 235-256, here: p. 244.

2 Ibid., p. 239-240.

3 SIMON KuPER: Een zondag voor de oorlog: Met de Gooise moordenaar naar Amsterdam. In: Hard Gras, special issue Ajax, de joden, Nederland 22 (2000), p. 9-20, here: p. 20; also: Ajax, the Dutch, the War. The Strange tale of Soccer during Europe's Darkest Hour. New York 2012.

4 STEFAN VAN DER Poel: Joodse stadjers. De joodse gemeenschap in de stad Groningen. Assen 2004, p. 12. Henceforth, all translations are by the authors, unless stated otherwise. 
tuated, whereas assimilation-oriented and mixed Jewish clubs have been either marginalised or neglected. They concluded that this selective memory rather echoes post-war guilt about the many Dutch-Jewish victims and the importance of Zionism within the Jewish world than reflects the multi-layered pre-war Jewish sports culture. ${ }^{5}$ It can be added that many Jews participated in non-Jewish clubs, a fact that has hardly been acknowledged.

Relevant as these remarks may be, we must nevertheless take into account that the Shoah influences our perception of this history, even if we are careful. In particular, the unequal availability of archival material has been shaped by it. It was only because the last secretary of Attila, Groningen's gymnastics club, survived the war that this club's archives are now publicly available. Furthermore, the only available memories are also those of survivors, resulting in the construction of a distinct pre-war Jewish sport identity. For instance, the cover of the biography of Jewish boxer and Holocaust survivor Ben Bril from Amsterdam depicts this champion of the Netherlands wearing boxer shorts with a distinct Star of David on them. Its title: Star of David as badge of honor. ${ }^{6}$

This essay tries to surpass the one-sided focus on Jewish sport as Zionist sport and takes Krüger's and Sanders' findings a step further. Following Catharine Raess' study on the entanglement of independence and interdependence in cultural contexts, and Erik Brouwer's eloquent multi-layered study of Amsterdam's Jewish gymnastic tradition, we understand sport as such, and Jewish sport in particular, as an intersectional category. ${ }^{7}$ It has been influenced by various intersecting identity categories such as religion, class and gender, while simultaneously influencing these categories itself. ${ }^{8}$ We also broaden the urban spectrum and focus on a broad range of sports clubs in three Dutch cities that have major Jewish populations: Amsterdam, Groningen and The Hague, representing different degrees of Jewish identity. The essay analyses the period from 1890, when the first Jewish clubs were founded, until 1940, when Nazi Germany invaded the

5 ARND KRÜGER and Astrid SANDERS: Jewish Sports in the Netherlands and the Problems of Selective Memory. In: Journal of Sport History 26 (1999), no. 2, p. 271-286.

6 E. g. Ed van OpzeELAND: Ben Bril. Davidsster als ereteken. Utrecht 2004. Also: STEven RosenFELD: Dansen om te overleven. De oorlogsjaren van bokslegende Ben Bril. Amsterdam 2015; MIKE SIlver: Stars in the Ring: Jewish Champions in the Golden Age of Boxing. Bowman, Littlefield 2016, p. 99.

7 CATHARIne RafF: Always Separate, Always Connected: Independence and Interdependence in Cultural Contexts of Development. New Jersey, London 2006; ERIK BROUWER: Spartacus. De Familiegeschiedenis van twee joodse olympiërs. Amsterdam 2009.

8 JoAN W. Sсотт: Gender: A Useful Category of Historical Analysis. In: The American Historical Review 91 (1986), no. 5, p. 1053-1075, there: p. 1054. 
Netherlands. It starts with a brief overview of the multi-layered Dutch Jewish population.

\section{Jews in the Netherlands}

Dutch Jews were not a single self-identifying group, but had either Portuguese, German or Central European backgrounds and were also divided along class lines. What they did have in common was the fact that in 1796 many of the restrictions against them had essentially been lifted, affording them equal rights. A similar emancipation process evolved for another religious minority, Roman Catholics, who until then had also been denied political and civil rights within the predominantly Calvinist state of the Netherlands.

In the mid-nineteenth century, as the state cut the funding to Jewish secular schools, children started attending state schools and interest in Jewish subjects plummeted. By 1870, most Jews had successfully integrated into Dutch class-structured society and increasingly began to see themselves as Dutch Jews, combining the best of Dutch identity and Jewishness. Author Sigmund Seeligmann even typified them as »species hollandia Judaica«, referring to a typical Dutch-Jewish identity which was basically nation-oriented, tolerant, moderate orthodox. They hardly identified themselves with international Jewishness. 9

Jews worked in all professions, although they did make up a disproportionally large number of the trade circles, and there were very few, if any, Jewish farmers. Some Jews had become wealthy, especially those trading in textile and working in shops, banks, or the diamond business, and there were a considerable number of doctors, lawyers and economists. At the same time, Amsterdam had a considerable Jewish proletariat. Overall, the core of the Jewish population consisted of »educated workers and (small) businesses «. ${ }^{10}$

At the turn of the $20^{\text {th }}$ century, Jews fitted perfectly within Dutch society, which was characterised by a politico-denominational segregation typified as »pillarisation«. Jews, but also Catholics, Protestants and social democrats had,

9 BART WALlET: Een familie van gemeenschapen. De dynamiek van joods Nederland in de naoorlogse periode. In: Achter de zuilen. Op zoek naar religie in naoorlogs Nederland. Ed. by Peter van Dam, James Kennedy and Friso Wielenga. Amsterdam 2014, p. 135-154, there: p. 137; VAN DER POEL, Joodse stadjers (see note 4), p. 7.

10 Hans Blom and Joel J. Cahen: Joodse Nederlanders, Nederlandse Joden en Joden in Nederland (1870-1940). In: Geschiedenis van de Joden in Nederland. Ed. by Hans Blom, Renate GERTRUD FUKS-MANSFELD and Ivo SchöFFER. Amsterdam 1995. p. 247-310, here: p. 265. 
to varying degrees, their own institutions and forms of socialising, while at the same time working together in the interest of the country and its economy. Matters of independence and interdependence, therefore, were at stake for all these groups, including Jews.

Despite their economic, social and cultural assimilation, most Jews remained moderately orthodox until 1940, although actual religiosity varied to a large degree. Moderate orthodox tradition had a strong Dutch flavour - being part of the community had more of a social than a religious function - and adopting a different religious practice would weaken the social aspect. Because the orthodox community was so Dutch in its organisational structures, it appealed to those desiring assimilation. In many social organisations, »Jews participated, usually known to be Jewish, without that being important « ${ }^{11}$ Furthermore, cherishing their own »Einheitsgemeinde«, most Dutch Jews regarded both liberal and ultra-orthodox movements with suspicion, even aversion. The liberal tradition that had started in Germany was not influential in the Netherlands. According to Dutch historians Blom and Cahen the emergence of a liberal Jewish movement was the result of public debate, which did not take place among Dutch Jews. Furthermore, while this liberal movement was pre-eminently practised by the bourgeoisie, most Dutch Jews were poor or lower middle-class.

Despite such successful integration into Dutch society (also acknowledged by contemporary non-Jews), stereotypes and anti-Semitic prejudices remained. Although anti-Semitism was considered improper and was not institutionalised, Christian anti-Judaism had never ceased to exist. Furthermore, there was a social form of anti-Semitism, in which Jews were accused of having too much influence as both »capitalists« and »Bolsheviks«. This type of social anti-Semitism was seemingly directed at foreign Jews, although Dutch Jews, too, were occasionally denied access to associations and clubs, also in the realm of sport. Further into the twentieth century, a third form of anti-Semitism emerged which depicted Jews as an inferior race. Its adherents ranged from social Darwinists to national socialists. $^{12}$

Partly because anti-Semitism was not ubiquitous, Zionism remained largely unpopular in the pre-war period. At its height, a mere 3 percent of Dutch Jews were members of the Dutch Zionist Union. Primarily, its adherents were radicalised young people from secularised well-to-do families, students and socialist Jews. ${ }^{13}$ Mainstream Dutch Jews considered Zionism a solution for other Jews,

11 Ibid., p. 281.

12 Ibid., p 281.

13 Ludy A. M. Giebels: De Zionistische beweging in Nederland, 1899-1941. Assen 1975; VAN DER PoEL, Joodse stadjers (see note 4), p. 113. 
particularly those living in less sympathetic countries, but the arrival of German refugees in the 1930s complicated matters. While Dutch Jews were anxious to preserve their position within society and even tried to intensify assimilation, they were increasingly being perceived as one distinct group, whose task it was to take care of their own. Although Dutch Jews did so out of solidarity with the Jewish refugees, they also feared for their own relationship with non-Jews and for the Dutch character of their community. ${ }^{14}$

\section{The Mixed Jewish Sports Culture of Amsterdam}

Amsterdam, the Dutch metropolis, held the largest section of Jewish inhabitants in the Netherlands. According to census figures, $10 \%$ of the Amsterdam population was Jewish (consisting of 80.000 in 1940) and Jewish sports culture there was mixed and multiform. It consisted of a range of clubs: football, boxing, gymnastics, athletics, korfball (a Dutch version of basketball) and rowing. In the shaping of identity, both religion and class were key factors.

Of all 24 Jewish football clubs in the country, three were located in Amsterdam. Based in the eastern part of Amsterdam, near the Jewish neighbourhood, football club Wilhelmina Vooruit (Wilhelmina Forward, WV) was founded in 1908 by a small group of schoolboys. Among them were Louis Aussen, who acted as chair, and secretary and treasurer Martijn Sajet. Both were 16 years old at the time. WV was a pioneer amongst Amsterdam's football clubs: the first to have a magazine and a youth department, it was also the organiser of many parties at which artists performed. Furthermore, WV was firmly based in the neighbourhood: new members were recruited from local schools. ${ }^{15}$ Sajet saw great diversity in $\mathrm{WV}$, an aspect for which he praised the club in retrospect:

[...] it is striking how strongly [players'] personalities differed off the field, in terms of religion, political opinions and profession. Intellectuals, manual labourers, office workers, traders, employers, employees, all of them played together at WV and knew no difference in ranks or social position or religion. ${ }^{16}$

14 Boв Moore: Refugees from Nazi Germany in the Netherlands 1933-1940. Dordrecht 1986.

15 VINCENT HUIS IN 'T VELD: »Een aantal HBS-jongens, die besloten voetbalclubje te gaan spelen« 1906-1920. In: Drie mooie geboorten: De oprichting van Wilhelmina Vooruit, Hortus en Eendracht Doet Winnen, en hoe hun groei bijna in de knop werd gebroken. Amsterdam 2008, p. 9-45, here: p. 9-38.

16 Ibid., p. 39. 
Sajet reiterated that sport, politics and religion should be separate spheres, and that all of WV's members are well aware of that. Maintaining that opinion, he became a board member of the national Royal Dutch Football Association (KNVB) in the 1930s. In spite of Sajet's good intentions, however, his assertion that WV's players included all social ranks was not quite true: WV remained mainly a middle and upper class club. ${ }^{17}$ That Jewish identity was not very outspoken is illustrated by the fact that the club named itself after the Dutch queen rather than an Old Testament hero.

Another Amsterdam-based club, Hortus Eendracht Doet Winnen (Hortus Unity Makes for Victories, HEDW $)^{18}$ also had a large proportion of Jewish members. Although neutral at the outset and playing in non-Jewish competitions, the number of Jews in the club increased over time, as some non-Jews did not like to join a "Jews' club « and chose to play elsewhere. ${ }^{19}$ This was especially the case after 1933, when German refugees joined HEDW. This brought about a heightened awareness of Jewish identity. Both WV and HEDW were opposed to the football match between the Netherlands and Germany in 1935, because Jews and political dissidents were banned from taking part in German sport. ${ }^{20}$

A gymnastics club that was supposed to be neutral, but in practice consisted mostly or entirely of Jews, was Spartacus, founded in 1886. Its members were mostly bourgeois, assimilated Jews, some of whom belonged to the city's wealthy upper bourgeoisie. While orthodox Jews rejected sport for fear of assimilation, Spartacus' members explicitly aimed at liberating Jews from their physical disadvantage. ${ }^{21}$ Other than a dispute between assimilated and orthodox Jews over sport, there was also an undercurrent of class struggle involved: Spartacus' members were bourgeois and did not see eye to eye with the socialist Jewish gymnastics club De Halter (The Dumb-bell, founded in the 1880s). ${ }^{22}$ Both clubs had a monolithic class culture which was cherished because they also functioned as marriage markets. A similar class background was preferred above shared Jewishness. ${ }^{23}$

17 Ibid., p. 39-41.

18 HEDW was itself a fusion of two clubs: Hortus, and Eendracht Doet Winnen.

19 VinCENT Huis IN 'T VELD: Koning voetbal beveelt: HEDW tussen fusie en oorlog 1931-1941. In: Drie mooie geboorten (see note 15), p. 180-217, see p. 211-212.

20 Evert DE Vos: „Verliest den moed toch niet«: WV en HEDW in de oorlog 1941-1945. In: Drie mooie geboorten (see note 15), p. 218-248, see p. 221-222.

21 Brouwer, Spartacus (see note 7), p. 12-33.

22 Ibid., p. 49-51.

23 Ibid., p. 130-135. 
Significant evidence of Spartacus' neutral disposition was the fact that some of its benefactors also financially supported neutral gymnastics clubs. Furthermore, one of its board members, lawyer Daniël Josephus Jitta, became the »sympathetic, able and dignified president « of the national Dutch Gymnastics Association (NGV) in 1881. During his long-lasting presidency, he aimed at the improvement of national physical strength and resilience through gymnastics. ${ }^{24}$

Rather than these bourgeois and middle class sports, lower class Jews took to either football or boxing. The latter, in particular, was distinctly a working class sport that attracted a fair number of Jews, as was the case in other cities such as New York and London which had a large Jewish (immigrant) population. ${ }^{25}$ At clubs like Olympia, Ursus and De Jonge Bokser (The Young Boxer), the sons of Jewish harbour labourers and manufacturers tried to become other Daniel Mendozas. Olympia, situated in the centre of the Jewish neighbourhood, was particularly popular. The muscularity of boxing, and also wrestling, corresponded with an awareness of the importance of Jewish self-defence, although Max Nordau's ideology of muscular Judaism was not explicitly discussed. In 1908, wrestler Jacob van Moppes, an apprentice in a butcher's shop, participated in the London Olympics.

During the 1920s, Amsterdam saw increasing attention paid to Jewish sport (a special propaganda committee was founded ${ }^{26}$ ), while certain Jewish circles also began to sympathise with Zionism. These, initially small, differences began to grow and tended to cause sharp divisions. ${ }^{27}$ This was reflected in the realm of sport. Kadimah, a sports and cultural club, founded in 1923 by shopkeeper Jacob Vaz Dias, co-organised the visit of Professor Chaim Weizmann to Amsterdam in 1928. This British chemist was the international president of the World Zionist Organisation and the embodiment of Zionism and Jewish unity. He was greeted and publicly fêted with a serenade by youth organisations, including Kadimah. The Zionist anthem Hatikwah was sung and Weizmann expressed his gratitude to the enthusiastic Zionist Amsterdam youth, calling on them to support the founding of the Jewish Homeland. Kadimah also welcomed another Zionist sports club to Amsterdam, Hakaoh from Vienna. Both Jewish and non-Jewish newspapers reported these visits, with Kadimah flags clearly visible on accompanying photo-

24 Theo Toвbosch: Uitverkoren zondebokken. Een familiegeschiedenis. Amsterdam 2010.

25 SUSAn TANANBaUm: Jewish Immigrants in London, 1880-1939. London 2014; STEPHEN RiesS: A Fighting Chance: The Jewish American Boxing Experience. American Jewish History 74 (1985), no. 3, p. 223-254.

26 Nieuw Israelietisch Weekblad, 14 July 1922.

27 Evelien Gans: De kleine verschillen die het leven uitmaken. Een historische studie naar joodse sociaal-democraten en socialistisch-zionisten in Nederland. Amsterdam 2002. 
graphs. ${ }^{28}$ Although this increasing turn towards Zionism did not involve all Jewish or semi-Jewish sports clubs, they were forced to face up to it. Spartacus, for instance, was confronted with financial problems because investors preferred to support clubs such as Kadimah and, particularly, Maccabi that were distinctly Jewish. These were not Jewish just in name, but also in culture - they were explicit in their muscular Jewishness. ${ }^{29}$

Particularly in the 1930s, due to the Nazis' rise to power in Germany, questions of identity inevitably became part of the self-awareness of all Amsterdam Jewish clubs. Spartacus began to withdraw from its original neutral position and became more outspokenly Jewish, although the club wished to refrain from politics. In April 1933, Spartacus as well as two other gymnastics clubs (Bato and Kracht \& Vlugheid) decided to cancel their annual trip to German Gymnastics Festivals. This decision was carried by the Amsterdam Gymnastics Association, in which Christian clubs also partook, even though not all of the latter agreed with this decision. ${ }^{30}$

With the Berlin Olympic Games of 1936, tensions increased. A year earlier, Jewish gymnasts, including Spartacus members, were already adamant that Dutch gymnasts should not participate in these Olympics. They won the vote, although much to the dismay of the president of the Dutch Gymnastics Association. ${ }^{31}$ The Berlin Olympics were a turning point in awareness of Jewish sport, particularly in boxing. Champion boxer Ben Bril, a member of Olympia, had boxed for his country at the Amsterdam Olympics in 1928. In the 1930s, however, he first turned down participation in the Olympics of Los Angeles in 1932, claiming that this was because of an anti-Semitic official in the Dutch Boxing Association. Four years later, he firmly refused to participate in the Berlin Games because of the Nazi exclusion of Jewish sport. Instead, he boxed at the Maccabi Games of 1935 in Antwerp, where he became champion, and he continued to take part in boxing matches in the Netherlands. At the beginning of the war, Bril and other Amsterdam Jewish boxers formed commando units to fight against Dutch national-socialist thugs.

28 Nieuw Israelietisch Weekblad, 20 April 1928; 29 June 1928; Algemeen Handelsblad, 6 December 1928.

29 Brouwer, Spartacus (see note 7), p. 145-146.

30 Ibid., p. 157-158.

31 Ibid., p. 164-166. 


\section{Groningen and Attila: Class and Zionism}

A mixed sport culture also existed in the city of Groningen, in the northern part of the Netherlands. Groningen's Jews had assimilated rapidly in the course of the nineteenth century, their (predominantly orthodox) religion being the only thing that distinguished them. They were hardly a coherent group; in fact differentiation increased in the first half of the $20^{\text {th }}$ century. Those who were economically successful moved away from the Jewish quarters and started their own clubs and schools. Religiously, they adapted to modernity by loosening their adherence to religious laws and traditions. Furthermore, within this group of wealthier Jews, women started to claim more freedom and more important positions from the beginning of the twentieth century. ${ }^{32}$

Some of Groningen's most prominent sports clubs (G.V.A.V.-Rapiditas, Be Quick and Velocitas) had Jewish members. Other Jews, however, joined the Jewish sports club Attila, founded in 1898 when Jewish members of a mixed gymnastics club broke away to found their own club. Historian Van der Poel claims that the reason they broke away is unclear; however, in an article in a Dutch weekly magazine for Jewish affairs, Attila's last secretary claimed in retrospect that they were tired of being just »tolerated«. Although Jews were not discriminated against, Attila members apparently felt they were not fully accepted within Groningen's sports culture. ${ }^{33}$ Attila was a club for wealthy, and often secular, Jews and it excluded the lower classes. Jubilee books spoke of sport in relation to building higher self-esteem for the Jewish people, although it also became clear that the club functioned as a means to meet friends and potential partners. A women's division had been added in 1906 and the club then also expanded the range of sports: as well as practising gymnastics, members could play football and tennis, and take part in athletics. ${ }^{34}$

Attila was both Jewish and Dutch and refused to express any allegiance towards Zionism, although there were Zionists amongst its membership. The club was not even explicit about its Jewish character. The club song made no mention of Judaism - instead, the song's last lines were: »[We] will give freely our goods and blood and life, if needs be, to our country and Queen «. ${ }^{35}$ The club competed

32 VAN DER POEL, Joodse stadjers (see note 4), p. 78-79.

33 Ibid., p. 88; ARNOLD J. vAN DAM: Gronings Attila zegde veertig jaar geleden groot jubileumfeest af. In: Nieuw Israëlitisch Weekblad (1978), found in: Attila Archief, Groninger Archieven, access number 858, inventory number 10.

34 VAN DER POEL, Joodse stadjers (see note 4), p. 88-90; KRÜGER/SANDERS, Jewish Sports in the Netherlands (see note 5).

35 Gedenkboek 1898-1928, p. 40. The Queen alluded to is Dutch Queen Wilhelmina. 
successfully in many sports and was also well known for its yearly demonstrations, which were enthusiastically discussed in local (non-Jewish) newspapers. There was a lively conviviality with other Jewish and non-Jewish clubs.

None of this was a problem until after the First World War. At that point, Zionist members left and founded two other clubs: Ivria, a gymnastics club, in 1919, and a football club, De Raven (later renamed Hakoah), in 1920. In part, this was the result of a growing and distinct Zionist movement in Groningen. Psychiatrist and Zionist leader Dr. Abraham Weinberg was the propagator of classic muscular Judaism. Sport and gymnastics would make Jews stronger, teach them »masculine virtues« like courage, love of order and community and above all self-consciousness - obviously qualities that he felt were lacking among Jews. Therefore, he forbade Zionist young men to play sports with or against non-Jews.

This Zionist segregation met with criticism amongst Attila members. A jubilee book referred to »the wedge of intolerance « that had done its damaging work. It was "saddening that some young people have made the gymnastics hall the domain of Zionist badgering, causing fission and weakening of the club's unity." Sport should serve physical and mental strength and not personal interest. In the same book, however, a member of a Maccabi association wrote a long article about the necessity for the Jewish people to play sports, referring to the concept of muscular Judaism. ${ }^{36}$

Again, this rejection of Zionism and the split within the Zionist youth - those who left Attila to form Ivria - are in line with the Dutch Jewish community in the twentieth century. As mentioned above, it was mainly wealthy, Jewish, secular young people that were attracted to Zionism, exactly Attila's membership base. At the same time, there were also wealthy, secular Jews opposed to Zionism, because they were so proud of, and happy with, their position in Dutch society. In the meanwhile, Attila's problematic relationship with Zionism lasted throughout the 1930s. In 1933 the assembly refused to join the Maccabi Union because members wished to keep the club »neutral «. ${ }^{37}$ However, its Jewish identity began to manifest itself more clearly. A merge with Ivria was discussed in 1935, but was eventually voted down. Ivria had attracted Zionist members of middle and lower classes, social circles that Attila members did not want to engage with. But this process provoked new debates in which Zionist sentiments began to emerge. Honorary

36 Feestgids Attila 1898-1923, Attila Archief, Groninger Archieven, access number 858, inventory number 6, p. 25-29.

37 Notulen ledenvergaderingen, jaarverslagen, lijsten van leden en donateurs, 1932-1941, Groninger Archieven, access number 858, inventory number 1. See for some newspaper reports about Attila's demonstrations: Aankondigingen, programma's en verslagen van sportevenementen, 1917, 1928-1938, Groninger Archieven, access number 858, inventory number 5. 
member Theodoor Levie, an influential factory owner and Zionist, initiated discussions on refusing new members if they had married outside of Judaism. This should even apply to those who already held a membership. The majority of Attila-members didn't agree, but compromised in refusing future members if they were in mixed marriages. ${ }^{38}$

With anti-Jewish measures increasing in Germany, Attila initially expressed its concern in the year reports but quickly moved on to better news about the club. Its members were ambivalent towards the German refugees who came in the 1930s. Although they did display some solidarity with them, many wondered if the stories they told were true. Germany's anti-Semitism was seen above all as a German problem. In addition, they feared that the presence of German Jews would cause anti-Semitism in the Netherlands and perhaps would even threaten their economic position. It was not until after the Pogromnacht in November 1938 that the situation in Germany was taken seriously. ${ }^{39}$ Then, the club decided to cancel its $35^{\text {th }}$ anniversary celebration and donate the money instead to the Jewish Refugee Committee.

\section{The Hague: "A Bastion against the Tide of Assimilation«}

The Hague, a rather traditional bourgeois city and the country's governmental centre, presents a third illustration of the variety in pre-war Dutch Jewish sports culture. It held the second largest Jewish community of the Netherlands, consisting of 17.000 people. The large majority were assimilated Jews, working in manufacture, governance or directing enterprises. In reaction to assimilation, several Jewish clubs were established during the 1920s and 1930s. Sports clubs functioned either within an assimilated context or were part of the counter-assimilation movement.

As well as arts and scouting, T.O.P. (Toneel, Ontwikkeling, Philantropie Theatre, Education, and Philanthropy) offered athletics, and tennis, although it would drop its sports activities in 1936. Korfball, athletics and gymnastics could be played at the Jewish Gymnastics Club 's-Gravenhage (The Hague). The two clubs also had female members, both on the field and on the board. A third

38 VAN DER POEL, Joodse stadjers (see note 4), p. 88-90; KRÜGER/SANDERS, Jewish Sports in the Netherlands (see note 5); Notulen, Attila Archief, Groninger Archieven.

39 VAN DER POEL, Joodse stadjers (see note 4), p. 125. 
club, De Ooievaars (The Storks) was a football club. ${ }^{40}$ This last, in particular, was appropriated by the city's social and religious establishment to function as a bulwark of Jewish identity. Two jubilee books (published in 1923 and 1936), emphasised the importance of sport for Jews, because sports strengthened not just physical fitness but also solidarity. Jewish sports clubs were preferred over mixed ones, because the latter tended to encourage unwanted assimilation. ${ }^{41}$ Among the authors were Isaac Rijs, director of a Jewish youth club house, and Isaac Maarsen, who at the age of 33 had become Chief Rabbi in The Hague in 1925. Maarsen devoted himself to teaching the congregation about Judaism and protecting it from external influences, such as the Reform movement, proselytising, mixed marriage and calendar reforms. ${ }^{42} \mathrm{He}$ held ties to De Ooievaars, attended its twenty-fifth anniversary reception, and gave his unequivocal view on Jewish sport that it was »a bastion [...] against [...] the tide of assimilation. « ${ }^{43}$

Despite this explicit rejection of assimilation, the club itself did not put so much emphasis on its responsibility for preserving Judaism. The boards spoke more of the difficulties in preparing lower-class boys for the responsibilities of club life than of their mission to cultivate a Jewish identity. ${ }^{44}$ Furthermore, De Ooievaars regularly expressed gratitude for the good relationships the club had with both the sporting world (i.e. non-Jewish clubs) and the Jewish world in The Hague.

Rabbi Maarsen often used the magazine Ha'moed De Vuurzuil (Pillar of fire) to disseminate his ideas. This "Fortnightly magazine for Jewish The Hague'» subtitled: „Official Magazine of The Hague's combined Jewish Neighbourhood, Culture, Sport and Youth Clubs« had two principal aims: cultivating and strength-

40 Joodsche Vereeniging T.O.P. In: Ha’amoed - De Vuurzuil, no. 2, 19 June 1931, p. 6; Joodsche Gymnastiekvereeniging »'s Gravenhage«. In: Ha’amoed, no. 2, 19 June 1931, p. 7; Joodsche Vereeniging T.O.P. In: Ha’amoed, no. 5, 31 July 1936, p. 7; Joodsche Gymnastiekvereeniging »'s Gravenhage«. In: Ha'amoed, no. 9, 25 September 1931, p. 11. Henceforth, the magazine's title will be shortened to Ha'amoed.

41 I. vAN Rijs: Het Jubileum van de Haagsche Voetbalvereeniging »De Ooievaars«. In: Jubileumnummer, p. 17-20; I. vaN Rijs: Het Vijfde Lustrum van de Haagsche Voetbalvereeniging »De Ooievaars «. In: Jubileumboek uitgegeven ter gelegenheid van het vijf en twintig jarig bestaand der Haagsche voetbal-vereeniging »De Ooievaars«. Ed. by HARRY DE HARTOG. 's Gravenhage, 1936, p. 23-27.

42 I. B. van CREvelD: Gebundeld Erfgoed: facetten van joods Den Haag. Den Haag 2001, p. 206. 43 De Ooievaars. In: Ha’amoed, 20 June 1936, p. 9; I. MAARSEN: Een Gezonde Geest en een Gezond Lichaam. In: Jubileumboek uitgegeven ter gelegenheid van het vijf en twintig jarig bestaand der Haagsche voetbal-vereeniging »De Ooievaars«. Ed. by HARRY DE HARTOG. ’s Gravenhage 1936, p. 7.

4425 Jaar Lief en Leed. In: Jubileumboek (see note 41), p. 43-80, see p. 73-74. 
ening the feeling of solidarity among Jews, spreading and fostering knowledge about Judaism and its ancient tradition, and a third, "which should be achieved by the aforementioned facts, that people learn to value and understand each other.$^{45}$ In pursuit of these aims, the magazine published articles on a range of Jewish subjects, including sports news, both domestic and foreign. And in addition, local Jewish clubs (sports as well as others) would report about their news and activities. Judging from the adverts placed in Ha'amoed, the intended audience was upper-middle class, although the magazine was intended to be accessible to all, including the under-educated. ${ }^{46}$

On its first pages, the magazine often ran Maarsen's explanation of the weekly portion of the Torah, national and international Jewish news, and some explanation about Jewish tradition and sometimes reviews of cultural events or books. After that, it moved to club announcements. The magazine also ran a children's and youth section, and from 1937 a women's section was included. Judging from the overall tone and the magazine's contributors, it can be concluded that the magazine and its participating clubs enjoyed closer ties with the religious establishment than was the case in Groningen and Amsterdam. Furthermore, most of the clubs' articles in Ha'amoed pertained to matches, demonstrations and outings. Similar phrasing was used to describe matches against Jewish and non-Jewish teams. ${ }^{47}$ However, there were contradictions: on the one hand, the magazine expressed assimilation and, simultaneously on the other, explicit Jewish, sometimes even Zionist, identity.

In 1931, the editors congratulated 's-Gravenhage on its twentieth anniversary, expressing the hope that »the club may continue its useful work, raising Jewish youth to be healthy, able-bodied Jewish men and women, for many years to come «. ${ }^{48}$ However, although 's-Gravenhage did encourage Jews, including Jewish married housewives, to join the club, it was mainly for health benefits and not for specific Jewish reasons. ${ }^{49}$

In June 1933, T.O.P, 's-Gravenhage and Ooievaars organised a Jewish sport festival, hosting games for all Jewish athletes in the Netherlands and visitors from Belgium, Germany and Britain. In an announcement, the festival was framed in

45 HARRY DE HARTOG: Een nieuw blad, en een nieuwe toekomst. In: Ha’amoed, no. 3, 3 July 1931, p. 4.

46 Ibid., p. 4.

47 See for example: Joodse Gymnastiekvereeniging »'s Gravenhage«. In: Ha’amoed, no. 3, 3 July 1931, p. 7.

48 Jubileum J.G.V. ’s Gravenhage. In: Ha’amoed, no. 19, 12 February 1932, p. 3.

49 Joodse Gymnastiekvereeniging »'s Gravenhage«. In: Ha’amoed, no. 12, 6 November 1931, p. 10. 
such a way as to show Jewish optimism in an increasingly grim world, as well as national and international Jewish solidarity and the importance of a healthy body for a healthy Jewish mind.$^{50}$ After the Jewish sports festival, however, the editors emphasised that politics should have no place in Jewish sports. Clubs could only function if there were no rifts along political lines. ${ }^{51}$

An article about the upcoming Maccabi Games in 1932 enthusiastically stated the growth of the Maccabi movement in Eastern Europe and the importance of Jews rising against anti-Semitic prejudices. However, the Netherlands were not mentioned in the list of Maccabi-minded countries. ${ }^{52}$ Later, a committee was established to found a "national Jewish sports movement « which aimed at joining the Maccabi World Association..$^{53}$ However, when Maccabi asked 's-Gravenhage to join and become a proper Zionist club, several members and non-members reiterated that sports clubs should be neutral and open to all, notwithstanding their ideas about Zionism. ${ }^{54}$ A proponent of Zionist sports then stated that Jewish sports clubs needed to cultivate Jewish consciousness, too, and that they could only do so by adopting Zionism as their ideology. Ha'amoed's editors replied that it was not the responsibility of a sports club to cultivate Jewish consciousness, but rather that of culture clubs. By its very nature Judaism was so diverse that there should and could not be one overarching ideology such as Zionism. ${ }^{55}$ An overwhelming majority of 's-Gravenhage's members had »turned out to possess the right sort of club feeling «. At their general meeting, they had therefore voted to remain as a neutral club. ${ }^{56}$ One member who had switched to Maccabi even asked to return to 's-Gravenhage because he felt that the political strife within the Dutch Zionist Movement made it impossible to play sport in a friendly and efficient way. His letter was published to show the "neutrals « that they had been right all along. ${ }^{57}$

However, contrary to this, an editorial a year later - after the twenty-fifth anniversary of 's-Gravenhage - commented on the purpose and status of Jewish sports clubs in The Hague, stating that their only goal was »to cultivate the Jewish youth into strong, powerful young men and women, who are not only prepared for the arduous struggle for life, but also to fulfil their duties towards our beloved

50 HARRY DE HARTOG: Welkom Joodsche Sportlui! In: Ha'amoed, no. 1, 2 June 1933, p. 2-3.

51 Eenheid of Tweedracht? In: Ha'amoed, no. 3, 30 June 1933, p. 2.

52 Monny S. SANTCRoos: Maccabiade 1932. In: Ha’amoed, no. 13, 20 November 1931, p. 9.

53 Makkabi-Wereldverbond. In: Ha'amoed, no. 20, 24 February 1933, p. 8.

54 Bewaar de Eenheid!!!!; Ingezonden and »Trouw aan onze Banier«. In: Ha’amoed, no. 3, 30 June 1933, p. 9.

55 Eendracht of Tweedracht? In: Ha'amoed, no. 4, 14 July 1933, p. 9.

56 Joodsche Gymnastiekvereeniging »’s Gravenhage«. In: Ha’amoed, no. 4, 14 July 1933, p. 10.

57 Joodsche Gymnastiekvereeniging »'s Gravenhage«. In: Ha’amoed, no. 17, 12 January 1934, p. 11. 
faith and to defend it against enemies«. On the other hand, it emphasised that The Hague's Jewish clubs were well-respected by both the (non-Jewish) sports establishment and the Jewish (religious, social) establishment. ${ }^{58}$

The religious establishment of The Hague obviously failed to claim sport unequivocally as part of their ideology. The cultivation of Jewish solidarity happened, to some extent, because people enjoyed playing sports within their own social circle, but there was no cultivation of a national, cultural or religious Jewish identity, as Maarsen would have wished for. The clubs simply aimed to play sports, and to play them well and for enjoyment. Eventually, Ha'amoed was split into a Jewish cultural and religious section on the one hand, and a section simply containing match results on the other.

Initially, Ha'amoed readers and editors did not express any concern that anti-Semitism might come to Holland. Stories of anti-Semitism in other countries were always treated sarcastically, with claims that the Dutch people were too good to be anti-Semites. ${ }^{59}$ The tone changed after an influx of large numbers of German refugees in the second half of the 1930s (for which The Hague's clubs organised sporting events). From 1938 onwards, especially, the atmosphere became charged. With the rise of anti-Semitism in Germany, De Ooievaars decided to skip a group outing to the Holland-Germany match, soon after the Pogromnacht. ${ }^{60}$ Furthermore, anti-Semitic incidents began to occur at matches. These led to the board of De Ooievaars urging its members and supporters not to engage in any discussion or react to insults during matches. If what was said was genuinely unpalatable, people could report the matter to the board, but it was important to keep up the good image of Judaism and refrain from fighting. ${ }^{61} \mathrm{~A}$ year and a half later, the war began. After another year and a half, all Jewish clubs were dissolved.

\section{Conclusion}

In 1928, the Olympic Games were held in Amsterdam, and, for the first time in Olympic history, women's gymnastics was part of the program. Twelve Dutch women, all members of gymnastic clubs from Amsterdam and The Hague performed so well at the three disciplines that they won a gold medal. This caused a

58 HARRY DE HARTOG: Vereenigingsleven. In: Ha’amoed, no. 22, 16 April 1937, p. 4-5, here: p. 4. 59 Uit de Joodsche Wereld. In: Ha’a moed, no. 11, 4 December 1936, p. 5-6.

60 HARRY DE HARTOG: Niet naar den voetbalwedstrijd Nederland-Duitschland. In: Ha'amoed, no. 12, 18 November 1938, p. 21.

61 HARRY DE HARTOG, De Ooievaars. In: Ha'amoed, no. 13, 2 December 1938, p. 23. 
wave of enthusiasm in the Dutch media which wrote of »excellent sportswomen« and »Orange success«. (Orange is the national colour of the Netherlands). No one mentioned at the time that about half of the team was of Jewish descent, nor that the coach, Gerrit Kleerekoper from Amsterdam, was also Jewish. This passed without comment until a Dutch sports journalist wrote about the team in 1994 in an article titled »After the Glory«. He had found out that four of the five gymnasts, together with their coach, had been murdered in Auschwitz and Sobibor. Gradually after this publication, public interest in the team grew, although mainly in the terrible fate of its Jewish members. The team became a Jewish team and a symbol for Jewish sport and identity. In 1997 they were listed in the International Jewish Sports Hall of Fame in Israel. In 2005 they were officially remembered during the National Remembrance of Sports Victims of the Second World War. In 2010 so-called Stolpersteine (stumble stones) were placed in front of the houses where they had lived.

This example refers to a broader cultural development of the last two decades, in which sportsmen and sportswomen of Jewish descent have been brought to the fore in Dutch collective memory. Mostly expressed during commemorations of the Second World War, it has been shaped by the frame of Jewish difference. It focuses on sport as an expression of Jewish, not Dutch identity, while accentuating Zionist tendencies in particular. Simultaneously, Jewish sport has been brought into the public eye by supporters of Ajax Amsterdam, who have appropriated Jewish identity. In both cases, Jewish sport is perceived through the lens of war and post-war developments, while neglecting or marginalising a much more diverse and multi-layered Jewish sports culture in pre-war Netherlands.

While historical research up until now has been scarce, this essay aimed at a revision by focusing instead on the diversity of Jewish clubs between 1890 and 1940. An analysis of Jewish sports culture in three cities uncovers a few trends. First, although the religious establishment was slightly wary of sport until the 1920s, Jews participated in sport on a broad level. They did so in neutral clubs, Jewish clubs with mixed membership, clubs for Jews only and those with a distinct Zionist identity. Second, class played an important role in this diversity. Predominantly assimilated, most bourgeois and middle class Jews played their sport in multi-religious clubs, although the number of separate Jewish clubs increased during the 1920s and particularly the 1930s. Mainly lower class Jews tended to associate with Jewish clubs in boxing and football, and sometimes also participated in socialist clubs. Their Dutchness was not at stake; like all inhabitants of the multi-religious Netherlands, they were first and foremost Dutch, and then Jewish.

Comparing the Dutch case with those of other countries, it can be placed somewhere between the strong identification with Nordau's muscular Judaism 
found in German speaking and Eastern European countries and the lighter version that existed in Britain and the US. ${ }^{62}$ There was some explicit mention of fostering Jewish identity, but also an identification with sport in order to achieve the benefits of sporting activity. The ideal of integration was not very apparent because most Jews were already very much integrated into Dutch society. Since this was a pillarised society, divided into confessional and ideological subcultures, Jewish sport - in all its diversity - fitted right in. It wasn't until the Nazi terror that all differentiation between Jewish sports clubs diminished and all its members were reduced to the one common denominator of being Jewish.

\section{Bionotes}

Marjet Derks, born 1958, is professor of Sport History at Radboud University in Nijmegen (the Netherlands), where she is principal investigator of the research group Sport History. She specializes in sport in relation to gender, religion, and race; sport and life courses; and the appropriation of sport in the political realm. Her current research pertains to sport as embodiment of progress, vitality and identity in the $20^{\text {th }}$ century and the ambiguous effects of large sport events. www.ru.nl/geschiedenis/onderzoek/culturele/ collectief-project-sportcultuur/english/sport-history-as-cultural-history/

Elisa Rodenburg, born 1992, has a BA from the University of Amsterdam and an MA in history from University College London. At UCL, she wrote an MA dissertation on press coverage of the 1936 Olympic Games. Currently, she is completing her research MA at the University of Amsterdam with a thesis on women's rowing in the Netherlands, 1945-1980.

62 See, for example, Daniel WiLdmann: Jewish Gymnasts and Their Corporeal Utopias in Imperial Germany. In: BRENNER/REUVENI (eds.), Emancipation through Muscles (see note 1), p. 27-43; and Gideon Reuveni: Sports and the Militarization of Jewish Society. In: BRENner/Reuveni (eds.), Emancipation through Muscles (see note 1), p. 44-61; DAVID DEE: Sport and British Jewry: Integration, ethnicity and anti-Semitism. Manchester 2013, p. 2-9; JENNA WeISSMAN Joselit: Fun and Games: The American Jewish Social Club. In: The Columbia History of Jews and Judaism in America. Ed. by MARC LeE RAPHAEL. New York 2008, p. 246-262. 